\title{
Detecting Aphanomyces Invadans in Pure Cultures and EUS-infected Fish Lesions by Applying PCR
}

\author{
Fatemeh Afzali ${ }^{1}$, Hassan Hj Mohd Daud ${ }^{2}$, Shiv Shankar ${ }^{3}$, M Shuaib Khan ${ }^{4}$, Samanesadat Afzali ${ }^{5}$ \\ 1,2,4Faculty of Veterinary Medicine, Universiti Putra Malaysia, 43400 UPM, Serdang, Selangor D.E, MALAYSIA \\ ${ }^{3}$ Department of Food Engineering, Mokpo National University, 61 Dorimri, Chungkyemyon, Muangun, REPUBLIC OF KOREA \\ ${ }^{5}$ Institute of Standards and Industrial Research of Iran, Sari, Mazandaran, IRAN \\ *Correspondence (Email): \\ s.f.a.845@gmail.com
}

\begin{abstract}
Aphanomyces invadans is an oomycete fungus which causes Epizootic Ulcerative Syndrome (EUS) disease in wide range of fresh and brackish water fish worldwide imposing serious economic losses. A diagnostic procedure, based on a polymerase chain reaction method (PCR) was developed to detect infection of fish with the A.invadans. A set of primers (1APM 1F and 1APM 6R) was used to specifically amplify A. invadans DNA. The PCR amplifies a $400 \mathrm{bp}$ amplicon. A protocol for the extraction of $A$. invadans DNA from infected fish tissue and pure fungal cultures was developed. The method was tested on seven EUS-susceptible fish species (snakehead, snakeskin gourami, moonlight gourami, koi carp, catfish, gold fish, climbing perch) and one EUS-resistant fish (tilapia), artificially infected with A. invadans and pure cultures of Aphanomyces spp., Saprolegnia spp., Achlya spp., and Allomyces sp. Detection of $A$. invadans was possible at the early stage of sampling, which was 24 hours post injection in both EUS-susceptible and resistant fish. Resistant fish was found to be PCR-negative after 6 days of inoculation but in susceptible fish PCR-positive results obtained even after day 28 or in dead fish. Therefore PCR may be a useful method for detection EUS infection in fish from early stage of disease onset.
\end{abstract}

Key words: PCR, EUS, Aphanomyces invadans, DNA extraction

\begin{tabular}{ll}
\hline $\mathbf{1 2 / 3 1 / 2 0 1 6}$ & Source of Support: Nil, No Conflict of Interest: Declared \\
\hline $\begin{array}{l}\text { This article is is licensed under a Creative Commons Attribution-NonCommercial 4.0 International License. } \\
\text { Attribution-NonCommercial (CC BY-NC) license lets others remix, tweak, and build upon work non-commercially, and although the new works must also } \\
\text { acknowledge \& be non-commercial. }\end{array}$
\end{tabular}

\section{INTRODUCTION}

Disease problems constitute the largest single cause of economic loss in aquaculture (Hutson, 2013; Jerry, 2013). Over the past several years, the development and application of molecular diagnostic techniques has initiated a revolution in the diagnosis and monitoring of infectious diseases. PCR-based systems to detect the etiologic agents of disease directly from clinical samples, without the need for culture, have been useful in rapid detection of uncultivable or fastidious microorganisms and allows for identification and better characterization of the pathogen (Tang et al., 1997). Polymerase Chain Reaction (PCR) is a rapid and highly sensitive molecular diagnostic method with a capacity to amplify from even a single molecule of DNA which can produce millions of copies of a single DNA segment in only a few hours. It is also very specific due to the nature and orientation of the oligo-nucleotide primers that are required to allow amplification to proceed (Shariff et al., 2000). PCR-based techniques may solve the problems associated with the identification of pathogenic A.invadans that is so difficult and time-consuming (Phadee et al., 2004). The current research aimed to develop diagnostic procedure based on DNA extraction and PCR technique suitable for the detection of A.inavdans from both fungi pure culture and fungal infected fish tissues from the early stages of disease. 


\section{Materials AND MethodS}

\section{Fungi and Fish tissues tested:}

All infected fish tissue (and oomycete strains used in this study for PCR were obtained from Afzali et al., (in press) study. EUS-infected fish muscle and skin which was intramuscularly injected with A.invadans isolate NJM9701 stored at $-85{ }^{\circ} \mathrm{C}$. A.invadans isolate MG001 and some other oomycete which was isolated from water and infected fish by previous study (Afzali et al., 2013) including: 12 isolates of Aphanomyces spp., 2 isolates of Saprolegnia spp., 2 isolates of Achlya spp., and 1 isolate of Allomyces sp. (Table I) were used for PCR assay in this study. In all experiments A.invadans isolate NJM9701 used as positive control.

Table 1: Oomycete isolates used for PCR assays

\begin{tabular}{|c|c|c|}
\hline Genus and Species & Isolate & Source \\
\hline Aphanomyces & & \\
A.invadans & NJM9701 & Naturally infected Ayu, Japan, 1997 \\
A. invadans & MG001 & Artificially EUS-infected Moonlight gourami, Malaysia \\
Aphanomyces sp. & ASFF01 & Fish Farm Water, Malaysia \\
Aphanomyces sp. & ASFF02 & Fish Farm Water, Malaysia \\
Aphanomyces sp. & ASFF03 & Fish Farm Water, Malaysia \\
Aphanomyces sp. & ASFF04 & Fish Farm Water, Malaysia \\
Aphanomyces sp. & ASF005 & Fish Farm Water, Malaysia \\
Aphanomyces sp. & ASE06 & Estuary, Malaysia \\
Aphanomyces sp. & ASP07 & Pound, Malaysia \\
Aphanomyces sp. & ASP08 & Pound, Malaysia \\
Aphanomyces sp. & ASP09 & Pound Malaysia \\
Aphanomyces sp. & ASL010 & Lake, Malaysia \\
Aphanomyces sp. & ASL011 & Lake, Malaysia \\
Aphanomyces sp. & ASL012 & Lake, Malaysia \\
\hline Saprolegnia & & \\
Saprolegnia sp. & SAWP01 & Pound, Malaysia \\
Saprolegnia sp. & SACF02 & Paturally infected Snakehead, Malaysia \\
\hline Achlya & & \\
Achlya sp. & ACWP01 & Pound, Malaysia \\
Achlya sp. & ACCF01 & \\
\hline Allomyces & & Naturally infected catfish, Malaysia \\
Allomyces sp. & ALFF02 & \\
\hline
\end{tabular}

DNA Preparation:

Several DNA extraction kit commercially available \{Ultra solid kit, Ultra clean soil (Mo Bio), Nuclean BACC2 (Amersham, UK), D-Neasy tissue kit (Qiagen)\} or new kits (Universe AllTM Genomic DNA Extraction Mini Kit for tissues and cultured cells) were tested which were already used in the literature to extract maximum amount of DNA from fish skin and muscle and fungal culture. Then the amount of yield DNA was calculated with a GeneQuant Pro RNA/DNA calculator (Amersham Pharmacia Biotech., USA) and electrophoresis were run to observe any band formation and comparing the results. During these preliminarily experiments no clear band was detected. So it was concluded that by applying some modifications, the desired result could be achieved using Universe AllTM Genomic DNA Extraction Mini Kit (Yeastern Biotech Co, Taiwan) which was not designed specifically for fungal DNA extraction. Therefore this new kit was chosen for extracting DNA from the rest of the samples in current experiments with some modifications as follow. To isolate Genomic DNA from small amount of samples, Lyticase enzyme and Sorbitol buffer were used. Fish skin and muscle, and fungal hyphae were ground physically by using strile plastic rod and incubated for a short period of time in water bath. This method eliminated the need for freezing of cells or tissues (for breaking cell walls) with liquid nitrogen, mechanical disruption, organic extraction, column DNA purification, or alcohol precipitation which were used in other protocols and found to be more safe and rapid with more efficiency.

DNA extraction from cultured hyphae:

For getting young fungal mycelia, actively growing colonies of each fungus were incubated at $25^{\circ} \mathrm{C}$ in $\mathrm{GY}$ broth for 4-6 days. Young mycelia about $0.5-1.0 \mathrm{~cm}$ in diameter were transferred to sterile $100-\mathrm{mm}$ petri dishes, and the GY (Glucose yeast) broth was decanted from the dish. The mycelia were washed with phosphate buffered saline (PBS) for two times, and then placed on tissue paper for liquid removal. Hyphal tips (30 mg) were excised with a sterile 
scalpel blade and transferred to $1.5 \mathrm{ml}$ centrifuge micro tube which was kept frozen at $-85^{\circ} \mathrm{C}$ until used (Vandersea et al., 2006). DNA extraction from the samples was performed using Universe AllTM Genomic DNA Extraction Mini Kit for cultured cells (Yeastern Biotech Co, Taiwan) using the following procedure for fungus isolates: As a pre-lysis step, the fungal hyphae were suspended in $600 \mu \mathrm{L}$ sorbitol buffer $(1.2 \mathrm{M}$ sorbotol; $10 \mathrm{mM} \mathrm{CaCl2;} 0.1 \mathrm{M} \mathrm{Tris-HCl} \mathrm{pH}$ 7.5; $35 \mathrm{mM}$ mercaptoethanol), then $200 \mu \mathrm{L}$ Lyticase enzyme (SIGMA, USA) was added and incubated at $30{ }^{\circ} \mathrm{C}$ for 30 minutes. The mixture was centrifuged for 10 minutes at 2,000g to harvest spheroplast, and the supernatant were removed. The tube was incubated at room temperature for 5 minutes. Two hundred $\mu \mathrm{L}$ Lysine buffer $\{50 \mathrm{mM}$ Tris$\mathrm{HCl}$ pH 7.4; 250 mM NaCl; 0.5\% Triton X100; 10\% glycerol; 1 mM DTT, PMSF, PI (Roche) $\}$ were added to the tube and mixed by vortexing, and incubated at $60{ }^{\circ} \mathrm{C}$ for 10 minutes until the sample lysis is clear. During incubation, the tube has been inverted every 3 minutes. For DNA Binding, $200 \mu \mathrm{L}$ of ethanol was added to the sample lysate and immediately mixed by vortexing for 10 seconds and any precipitation was broke up by pipetting. The DNA was trapped within wash step by adding $400 \mu \mathrm{l}$ of Washing Buffer (50 mM Tris-HCl, pH 7.5; 10 mM EDTA; 125 mM $\mathrm{NaCl}$ ) to the samples and centrifuging at 13,000g for 30 seconds. The flow-through discarded and the wash step was repeated by adding $600 \mu \mathrm{L}$ of washing buffer to the samples. The tube was centrifuged at $13,000 \mathrm{~g}$ for 30 seconds and the flow-through was discarded. $200 \mu \mathrm{L}$ Elution buffer $(50 \mathrm{mM} \mathrm{NaCl}$; Tris-HCl, pH 7.5; $0.1 \mathrm{mM}$ PMSF; 5 mM EDTA; $1 \%$ SDS w/v) was pre-heated in a $60{ }^{\circ} \mathrm{C}$ water-bath to be used for DNA elution. The dried column was transferred into a clean $1.5 \mathrm{~mL}$ micro-centrifuge tube and $100 \mu \mathrm{L}$ of pre-heated Elution buffer was added to the centre of the column matrix. After 3-5 minutes and absorbing buffer by the matrix, column matrix was centrifuged at $13,000 \mathrm{~g}$ for 30 seconds to elute purified DNA and the DNA solution was stored at $4^{\circ} \mathrm{C}$ until used.

\section{DNA extraction from fish tissue:}

All fish \{snakehead, Channa striata (Bloch); moonlight gourami, Trichogaster microlepis (Regan); snakeskin gourami, Trichopodus pectoralis (Regan); koi carp, Cyprinus carpio (Linnaeus); broadhead catfish, Clarias macrocephalus (Günther); goldfish, Carasius auratus (Linnaeus); climbing perch, Anabas testudineus (Bloch); and tilapia, Oreochromis niloticus (Linnaeus)\} intramuscularly injected with $A$. invadans (infected fish samples) and control fish (non-infected fish samples) were sliced for DNA extraction. The muscles from the lesions were taken with scissors and razor blade and were transferred into a $1.5 \mathrm{~mL}$ micro tube stored at $-85^{\circ} \mathrm{C}$ until needed. DNA from fish tissues was extracted from $50 \mathrm{mg}$ of tissue using Universe AllTM Genomic DNA Extraction Mini Kit for animal tissues (Yeastern Biotech Co, Taiwan) using the following procedure for fish muscle: For tissue dissociation, $30 \mathrm{mg}$ of fish muscle was cut up and transferred it to a $1.5 \mathrm{~mL}$ micro-centrifuge tube and micro-pestle was used to grind the tissue to a pulp. $200 \mu \mathrm{L}$ of Lysine buffer was added to the tube and homogenizing the sample tissue continued by grinding. $12 \mu \mathrm{L}$ of Proteinase $\mathrm{K}$ was added to the sample mixture and mix by shaking vigorously, and then incubated at $60{ }^{\circ} \mathrm{C}$ for 30 minutes to lyse the sample. During incubation, the tube has been inverted every 5 minutes. $200 \mu \mathrm{L}$ of Lysine buffer was added and mix by shaking vigorously for 5 seconds, then incubated at $60{ }^{\circ} \mathrm{C}$ for at least 20 minutes to ensure the sample lysate is clear. During incubation, the tube has been inverted every 5 minutes. DNA binding and washing steps were done according to the same methods as described above for cultured hyphae and DNA solution was stored at $4{ }^{\circ} \mathrm{C}$ until used.

\section{Aphanomyces invadans-specific primers:}

The primer set (1APM 1F 5'-ATCGCTGCACTCGTCGTGAA-3' and 1APM 6R 5'- CCAGTTGCACCATAACTTGTG3',) which were designed based on the sequences of cloned expression genes of A. invadans (NJM 9803) by Phadaee et al., (2004) was chosen to be used in this study. This is a specific - specific primer and could detect only fish pathogenic $A$. invadans.

\section{Single PCR assay:}

A number of unsusccessful trials were completed to obtain suitable concentration of PCR reaction mixture. Finally following protocol was applied: Taq 2 X Master Mix DNA Polymerase $(12.5 \mu \mathrm{L})$ (Vivantis, USA) containing 1.25 unit Taq DNA Polymerase, $1.5 \mathrm{mM} \mathrm{MgCl} 2$ and $0.2 \mathrm{mM}$ deoxynucleotide triphosphate (dNTPs) in DNA polymerase 1X buffer (Vibuffer A) added with $0.5 \mu \mathrm{L}$ each primer (Fwd/Rev) and $5 \mu \mathrm{L}$ of DNA template were mixed and adjusted to the $25 \mu \mathrm{L}$ final volume using $6.5 \mu \mathrm{L}$ nuclease-free water. Amplifications were performed using Eppendorf Mastercycler® pro, Thermal Cycler (Vapo.Protect, USA) according to Padaee et al. (2004) cycling protocol with some modifications. PCR amplification was processed by 30 cycles (for both fungal culture and fish skin and muscle tissues), since the clear band was not detected by applying 35 cycles which was used in Padaee and their colleagues's study. In addition the denaturation degree was modified and increased by 2 degrees. The initial denaturation at $94{ }^{\circ} \mathrm{C}$ for 5 min was performed, and followed by 30 cycles of amplification $\left(94{ }^{\circ} \mathrm{C}\right.$ for $30 \mathrm{~s}, 65^{\circ} \mathrm{C}$ for $30 \mathrm{~s}$ and $72{ }^{\circ} \mathrm{C}$ for 1 min) and by postextension with a $5 \mathrm{~min}$ extension at $72{ }^{\circ} \mathrm{C}$. Additional negative control (with no template DNA) amplifications using primers were performed to ensure that reagents used were not contaminated with extraneous template DNA. 
Agarose Gel Electrophoresis:

Polymerase chain reaction (PCR) products were analyzed by $2 \%$ Agarose gel electrophoresis which was placed in the microwave and heated for about 2-3 minutes. For staining agarose gels and detecting nucleic acid, both traditional Ethidium bromide stain and RedSafe TM Nucleic Acid Staining Solution (20,000x) were tried to obtain maximum efficiency. Although both staining protocols were similar, RedSafe found to be as sensitive as Ethidium bromide or even more. Thus because of its safety and non-carcinogenic characteristics as nucleic acid stain without hazard waste, it was chosen instead of Ethidium bromide for detecting nucleic acid in agarose gels in current experiments. Gel solution was stained with $0.05 \mu \mathrm{L} / \mathrm{mL}$ of RedSafe Nucleic Acid Staining Solution (20,000x), and the flask was swirled gently to mix the solution and avoid forming bubbles. Gel solution was poured into the gel tray until the comb teeth are immersed and allowed to be cool until solidified. In contrast with existed protocols, the amount of PCR product, DNA dye and marker were increased in current assay to obtain the clear band. Eight $\mu \mathrm{L}$ of PCR products and $2 \mu \mathrm{L}$ of $6 x$ loading dye were loaded in each lane. Electrophoresis was conducted at $100 \mathrm{~V}$ for 60 min in lx TBE buffer (Tris-borate). A DNA marker $(4 \mu \mathrm{L})$ was also run in parallel to approximate the size of the PCR products (the target product was $400 \mathrm{bp}$ ). The bands was detected under UV illumination and photo graphed by an Alpha imager machine.

\section{RESULTS}

The DNA extraction protocol applied in this study was succeeded to isolate A.invadans genomic DNA from fish muscle and pure cultured fungus, and the developed PCR assay by using primer set (1APM 1 F, 1APM 6R) were detected A.inavadns showing clear bands on the $400 \mathrm{bp}$. The results of the PCR assays of all clinical specimens were presented in Table II.

Table 2: Clinical Specimens were tested in the PCR assays. Amplification and absence of amplification are shown as + and - respectively.

\begin{tabular}{|c|c|c|c|}
\hline Samples & Isolate & Amplification & Absence of Amplification \\
\hline Aphanomyces & & & \\
A.invadans & NJM9701 & + & - \\
A. invadans & MG001 & + & - \\
Aphanomyces sp. & ASFF01 & & - \\
Aphanomyces sp. & ASFF02 & & - \\
Aphanomyces sp. & ASFF03 & & - \\
Aphanomyces sp. & ASFF04 & & - \\
Aphanomyces sp. & ASFF05 & & - \\
Aphanomyces sp. & ASE06 & & - \\
Aphanomyces sp. & ASP07 & & - \\
Aphanomyces sp. & ASP08 & & - \\
Aphanomyces sp. & ASP09 & & - \\
Aphanomyces sp. & ASL010 & & - \\
Aphanomyces sp. & ASL011 & & - \\
Aphanomyces sp. & ASL012 & & - \\
\hline Other oomycetes & & & - \\
Saprolegnia sp. & SAWP01 & & - \\
Saprolegnia sp. & SACF02 & & - \\
Achlya sp. & ACWP01 & & - \\
Achlya sp. & ACCF01 & & - \\
Allomyces sp. & ALFF02 & & - \\
Fish Muscle Tissues & & & - \\
Channa striata & & $+(1-21 \mathrm{dpi})$ & - \\
Trichogaster microlepis & & $+(1-14 \mathrm{dpi})$ & - \\
Trichopodus pectoralis & & $+(1-14 \mathrm{dpi})$ & - \\
Cyprinus carpio(Koi) & & $+(1-18 \mathrm{dpi})$ & - \\
Clarias macrocephalus & & $+(1-20 \mathrm{dpi})$ & - \\
Carasius auratus & & $+(1-22 \mathrm{dpi})$ & \\
Anabas testudineus & & $+(1-28 \mathrm{dpi})$ & - \\
Oreochromis niloticus & & & - \\
\hline & & & - \\
\hline & & \\
\hline
\end{tabular}




\section{Detection of Aphanomyces invadans in Fish Muscle:}

Polymerase chain reaction analysis of A.invadans-infected fish using primers (1APM 1 F, 1APM 6R) was visualized clearly as a band in eight infected fish species. Of 22 fish infected with A. invadans spores in each spices, PCR amplifications of the expected size (400 bp) were obtained from 20 EUS-infected snakehead within the first 21 day of the trial (Fig. 1). Twenty two moonlight gourami (Fig. 2a) and snakeskin gourami (Fig. 2b) and 21 Koi carp were tested clearly positive by PCR within the first 14 day of the trial (Fig. 3). A. invadans DNA detected in 20 EUS-infected catfish (Fig. 4), 22 goldfish (Fig. 5) and 20 climbing perch (Fig. 6) within the first 20, 22 and 28 day of post-injection respectively. However, of 22 tilapia infected with A. invadans spores, 15 were tested positive by PCR within 6 day of post-injection and after day 6, no more positive PCR results were obtained from tilapia (Fig. 7). All individuals in the control group (Tissues from non lesioned fish) tested negative for the presence of $A$. invadans by PCR.

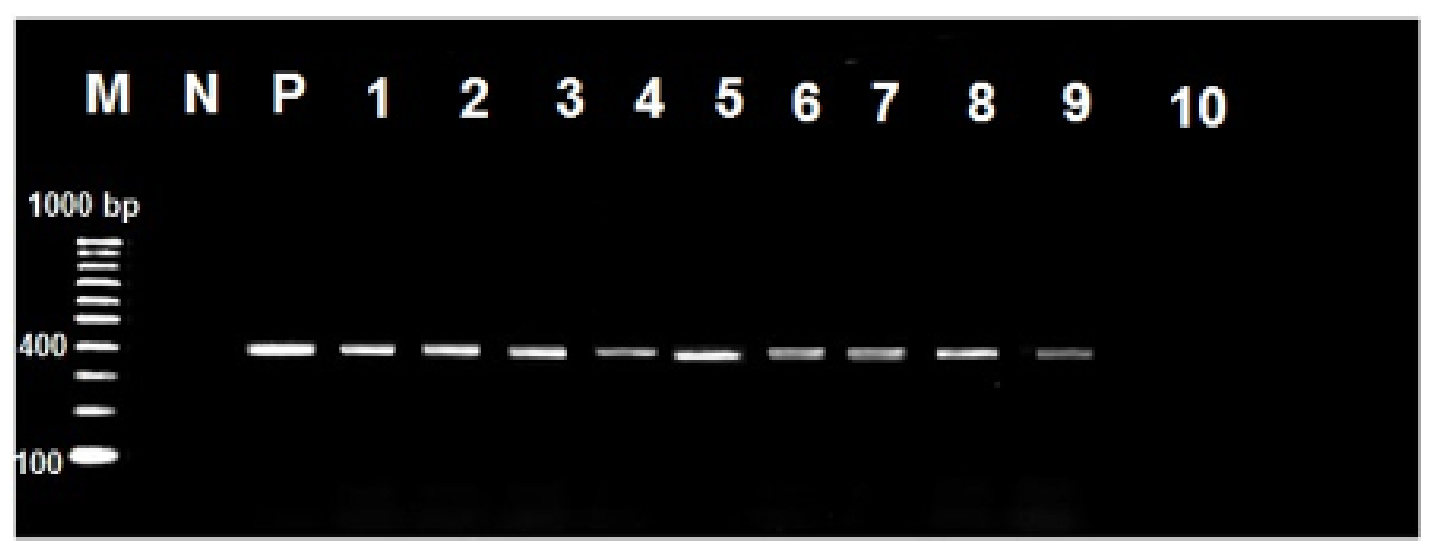

Fig. 1 Agarose gel showing the PCR products, from snakehead fish tissue DNA obtained by amplification of genomic DNA of snakehead lesion infected with A.invadans NJM9701. The left margin in figure (M) indicates the position of size markers in base pairs (100-1000 bp). Lane N: negative control with no DNA template. Lanes P: positive control with genomic DNA of pure cultured A. invadans NJM 9701. Lanes 1-9: genomic DNA of intact snakehead from day 1, 2, 4, 6, 8, 10, 12, 14 and 21 post-injection. Lane 10: genomic DNA from non lesioned snakehead injected with sterilized tab water.

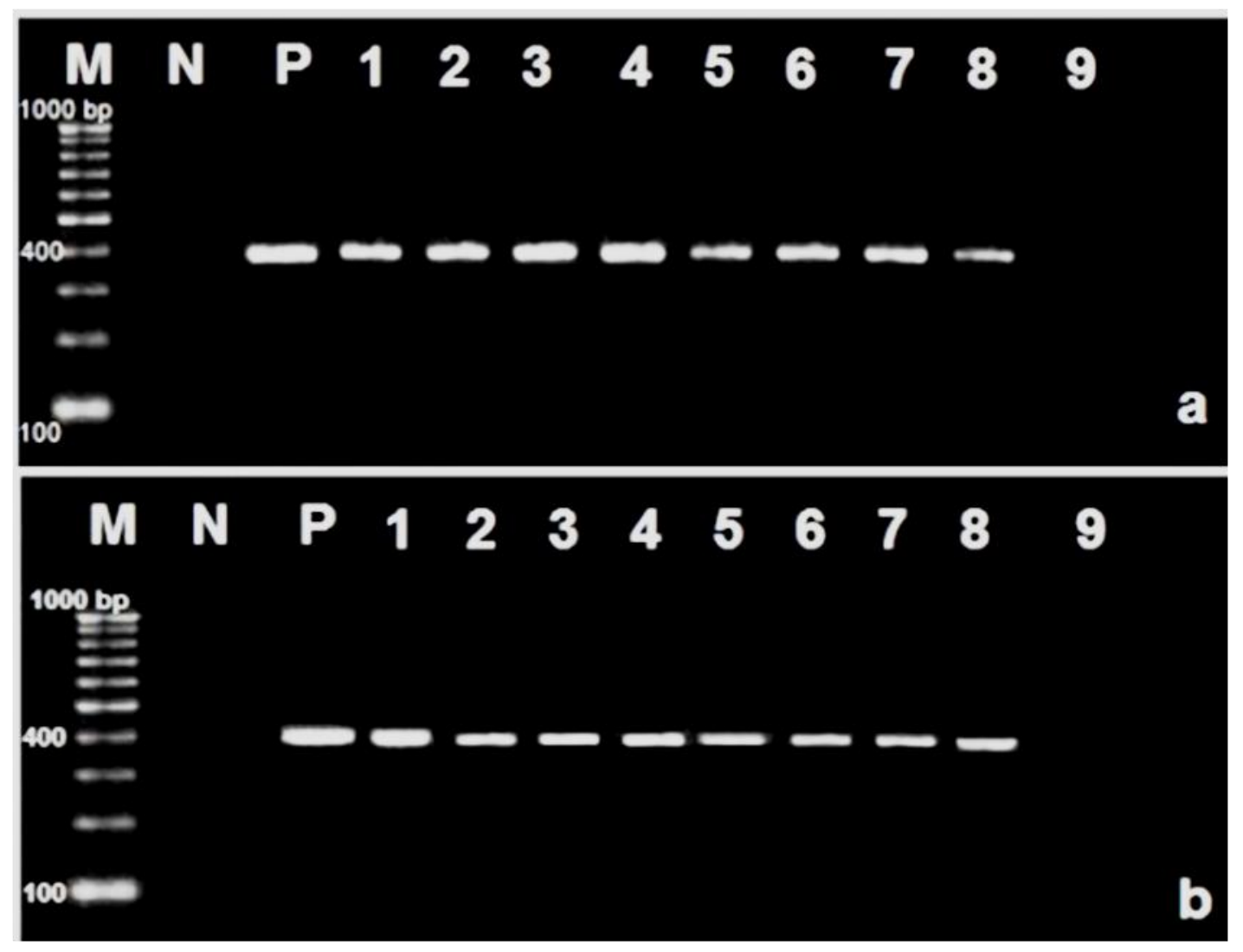


Fig. 2 Agarose gel showing the PCR products, from moon light gourami (a) and snakeskin gourami (b) fish muscle DNA obtained by amplification of genomic DNA of gouramies lesion infected with A.invadans NJM9701. The left margin in figure (M) indicates the position of size markers in base pairs (100-1000 bp). Lane N: negative control with no DNA template. Lanes P: positive control with genomic DNA of pure cultured A. invadans NJM 9701. Lanes 1-8: genomic DNA of intact gouramies from day 1, 2, 4, 6, 8, 10, 12 and 14 post-injection. Lane 10: genomic DNA from non lesioned gouramies injected with sterilized tab water.

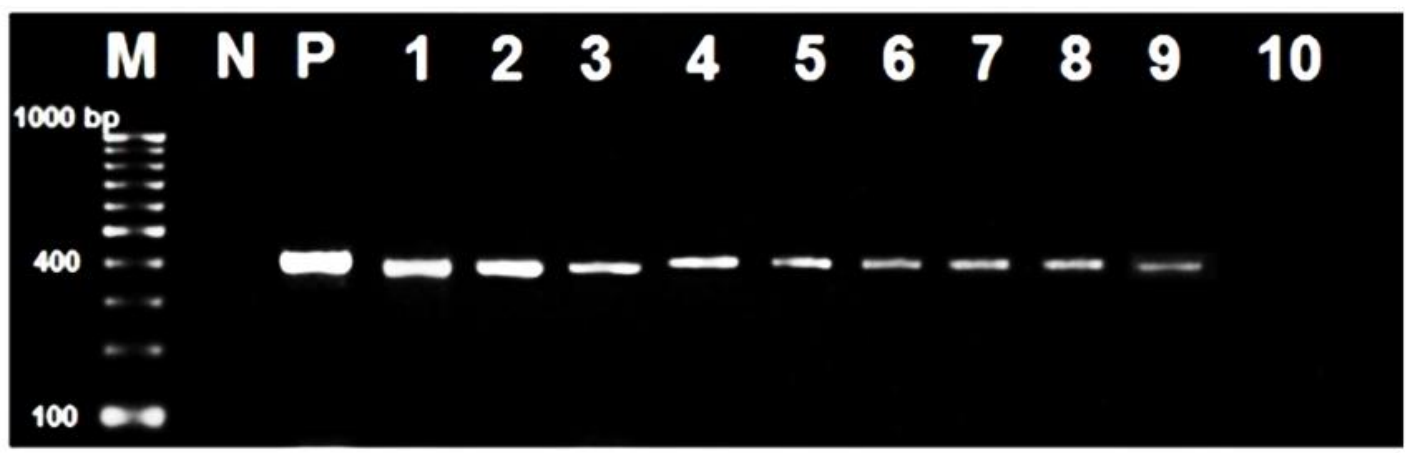

Fig. 3 Agarose gel showing the PCR products, from Koi carp fish muscle DNA obtained by amplification of genomic DNA of koi carp infected with A.invadans NJM9701. The left margin in figure (M) indicates the position of size markers in base pairs (100-1000 bp). Lane N: negative control with no DNA template. Lanes P: positive control with genomic DNA of pure cultured A. invadans NJM 9701. Lanes 1-9: genomic DNA of intact koi carp from day 1, 2, 4, 6, 8, 10, 12, 14 and 18 post-injection. Lane 10: genomic DNA from non lesioned koi carp injected with sterilized tab water.

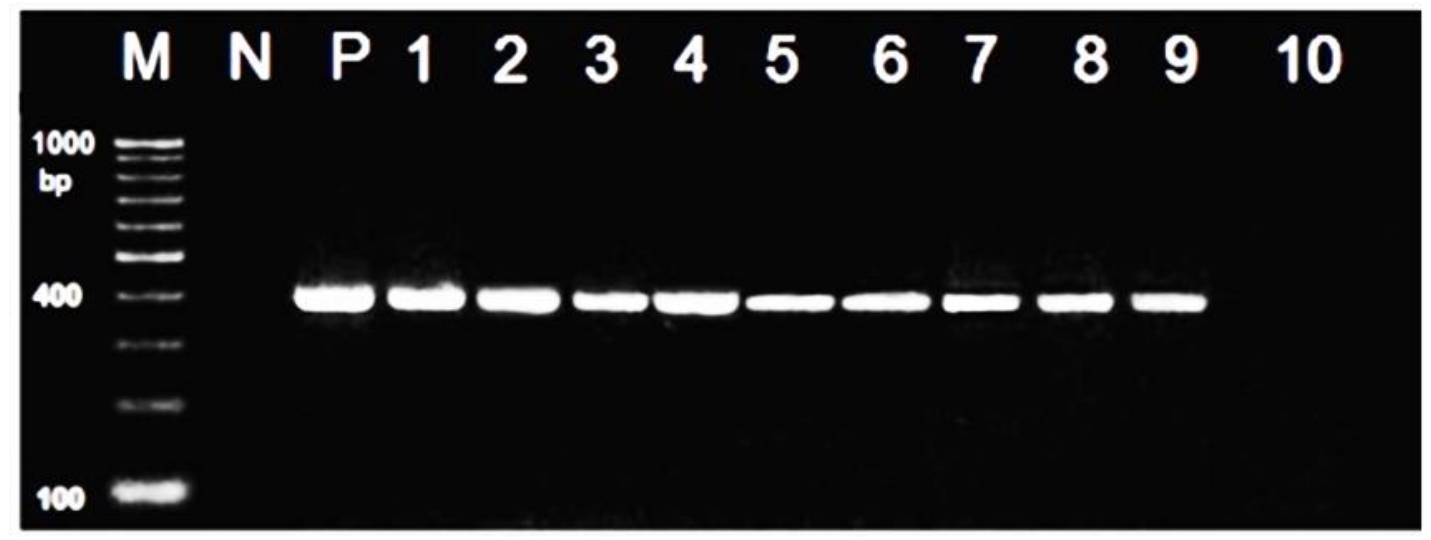

Fig. 4 Agarose gel showing the PCR products, from catfish muscle DNA obtained by amplification of genomic DNA of catfish infected with A.invadans NJM9701. The left margin in figure (M) indicates the position of size markers in base pairs (100-1000 bp). Lane N: negative control with no DNA template. Lanes P: positive control with genomic DNA of pure cultured $A$. invadans NJM 9701. Lanes 1-9: genomic DNA of intact catfish from day 1, 2, 4, 6, 8, 10, 12, 14 and 20 post-injection. Lane 10: genomic DNA from non lesioned catfish injected with sterilized tab water.

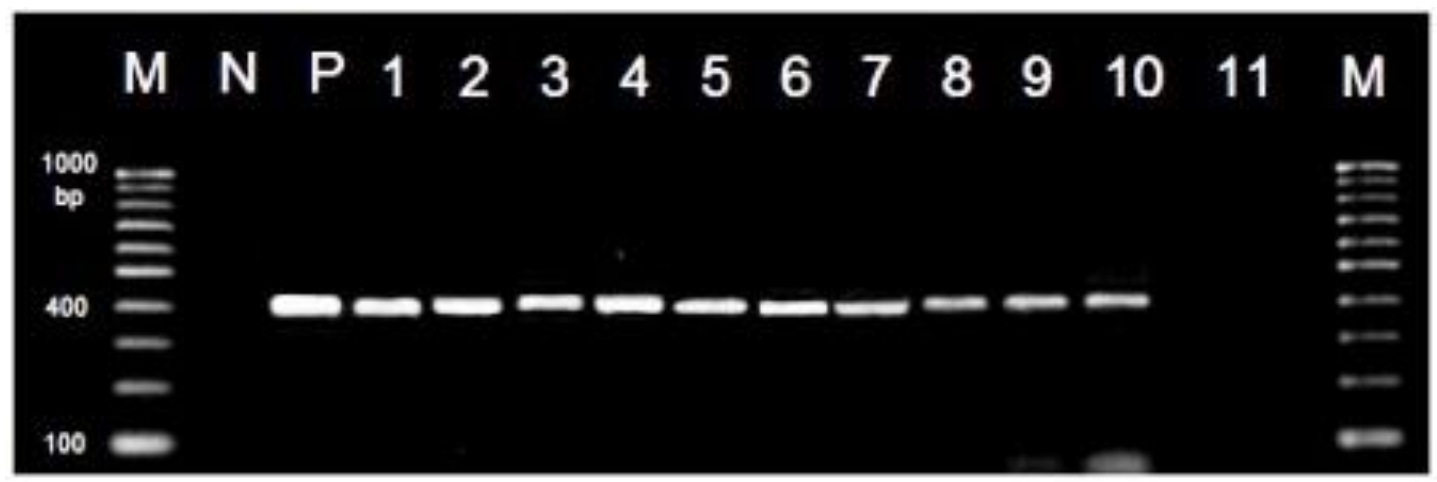

Fig. 5 Agarose gel showing the PCR products, from goldfish muscle tissue DNA obtained by amplification of genomic DNA of goldfish lesion infected with A.invadans NJM9701. The left and right margins in figure (M) indicate the position of size markers in base pairs (100-1000 bp). Lane N: negative control with no DNA template. Lane P: 
positive control with genomic DNA of pure cultured $A$. invadans NJM 9701. Lanes 1-10: genomic DNA of intact goldfish from day 1, 2, 4, 6, 8, 10, 12, 14, 21 and 22 post-injection. Lane 11: genomic DNA from non lesioned goldfish injected with sterilized tab water.

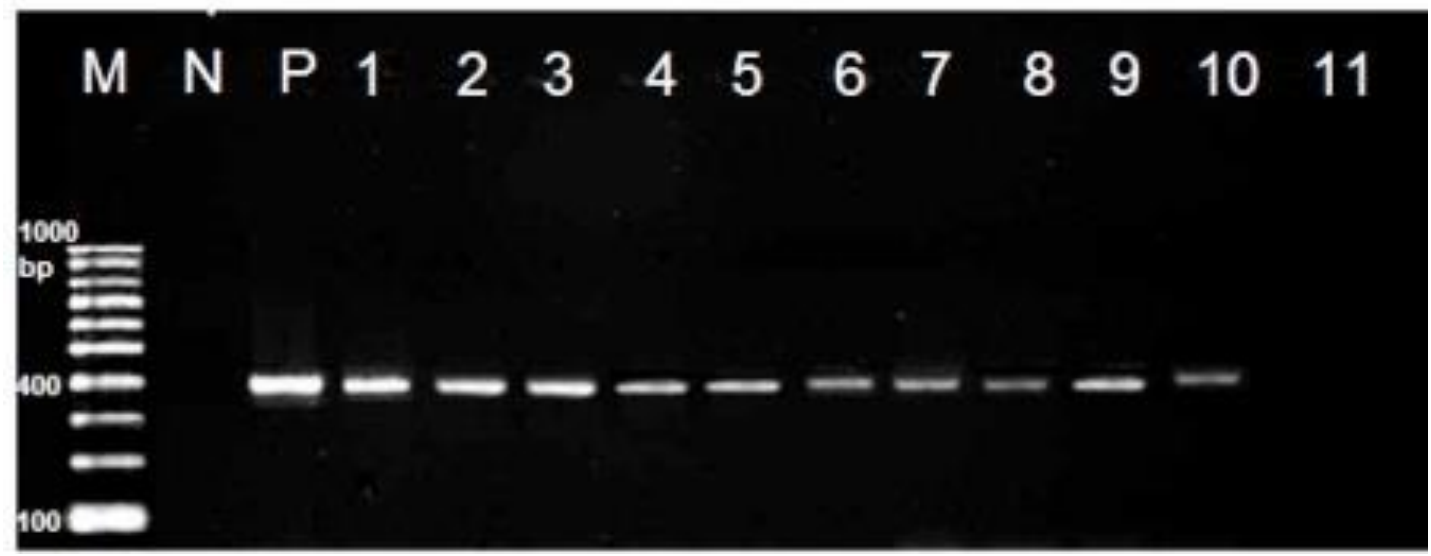

Fig. 6 Agarose gel showing the PCR products, from climbing perch muscle tissue DNA obtained by amplification of genomic DNA of fish lesion infected with A.invadans NJM9701. The left margin in figure (M) indicates the position of size markers in base pairs (100-1000 bp). Lane N: negative control with no DNA template. Lane P: positive control with genomic DNA of pure cultured $A$. invadans NJM 9701. Lanes 1-10: genomic DNA of intact climbing perch from day 1, 2, 4, 6, 8, 10, 12, 14, 21 and 28 post-injection. Lane 11: genomic DNA from non lesioned climbing perch injected with sterilized tab water.

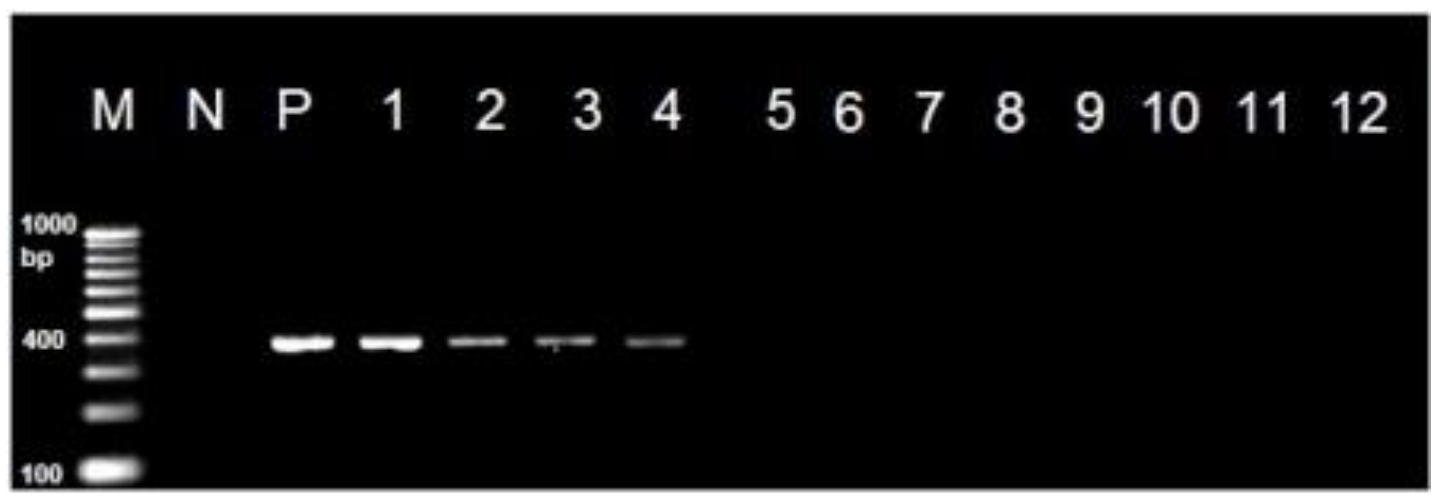

Fig. 7 Agarose gel showing the PCR products, from Tilapia muscle tissue DNA obtained by amplification of genomic DNA of fish lesion infected with A.invadans NJM9701. The left margin in figure (M) indicates the position of size markers in base pairs (100-1000 bp). Lane N: negative control with no DNA template. Lane P: positive control with genomic DNA of pure cultured A. invadans NJM 9701. Lanes 1-11: genomic DNA of intact Tilapia from day 1, 2, $4,6,8,10,12,14,21,28$ and 35 post-injection. Lane 12: genomic DNA from non lesioned Tilapia injected with sterilized tab water.

Experiments testing the potential cross-reactivity of the A. invadans-specific PCR assay were performed with genomic DNA of other oomycete species. The diagnostic tests were used on 12 Aphanomyces isolates, and 5 other fungi (two Achlya spp., two Saprolegnia spp., isolate and one Allomyces sp. isolate) and control samples (with no DNA template) which all were PCR-negative.

\section{Discussion AND CONCLUSION}

Previous studies proved that the isolation of Aphanomyces invadans from the lesions has been difficult. Even after successful isolation, the identification of the pathogen is hard, because of lack of sexual organs which are necessary for acute identification of oomycetes and also the growth rates is known to change after long periods of subculture. Developing rapid and sensitive diagnosis test for detection pathogen in the early stage of EUS is essential to prevent the infection, so the PCR method would be very useful for the rapid diagnosis of this infection. This diagnostic technique has several advantages over traditional identification methods. One of the most advantages of this technique is that fungus isolation is not required to make a diagnosis.

In the present study, we have used new DNA extraction protocols which could successfully isolate A.invadans DNA from pure culture and infected fish lesions. By applying these methods, genomic DNA was extracted from a small 
amount of samples simply by incubation in buffer for a short period of time in water bath. This method eliminated the need for freezing of cells or tissues (for breaking cell walls) with liquid nitrogen, mechanical disruption, organic extraction, column DNA purification, or alcohol precipitation and found to be more safe and rapid compare to other protocols which we have tried within our pilot study.

In present study we have adapted the PCR protocol described by padaee et al. (2004) by using their designed primer set (1APM 1F, 1APM 6R). A.inavdans DNA was isolated from both infected fish and pure cultures and clear band were appeared in $400 \mathrm{bp}$ which was the expected size of PCR product. The results of PCR assay of our study showed that this technique would be able to detect EUS from 24 hours post injection in fish. All highly susceptible fish like snakehead, gouramies, koi carp, catfish, goldfish and climbing perch, were found to be PCR positive until they were died, while, in Tilapia no PCR positive samples were found after day 6 post injection which means resistant fish can easily digest and degenerate A.invadans within the first week of infection.

The applied primer set in this study was also used to confirm the identification of saprophytic Aphanomyces, and other oomycete have been isolated within chapter 3 of present study. The results of PCR assays of these isolates were negative and showed all 12 Aphanomyces isolates were non-pathogenic. These experiments confirmed that the A.invadans PCR assay was species specific and did not amplify DNA from related oomycete species. The present study also included experimental controls for confirming the accuracy of a PCR assay. These included a PCR inhibition control to rule out the possibility of false-negative samples and a blank extraction control to identify potential DNA contamination during DNA extraction procedures.

Previous studies were designed different DNA extraction and PCR protocols to detect A.inavdans isolates by using different primer sets. Blazer et al. (2002) developed PCR assay and applied it successfully to diagnose A.invadans in formalin- fixed and paraffin-embedded naturally infected fish tissues by using the FP1-2 primers (FP1 5\&AAGGCTTGTGCTGAGCTCACACTC-3 $₫$ and FP25 $ф-G A T G G C T A A G G T T T C A G T A T G T A G-3 \notin)$.

In similar study, Lilley et al. (2003) tested a species-specific PCR assay on cultures of several $A$. invadans isolates and other oomycetes by applying 2 primer sets (FP1-2 primers and APH3 $5 \not$-ATAAGGCTTGTGCTGAGC and APH4 $5 \not-$ CATTTCTGATGGCTAAGG primers) in their assay. Their technique successfully detected A.inavdans isolates from different geographical areas but was unable to detect other pathogenic Aphanomyces isolates, saprophytic Aphanomyces or other oomycetes fungi. The possibility of using these primer sets for in situ hybridization, or for detecting A. invadans DNA in water samples from ponds or tanks containing EUS-infected fish was not proved in their study. It is likely that the level of DNA in of those samples was below the detection threshold of applied technique, or maybe some debris in the water samples disrupted the PCR assay. But the DNA primers, designed from ITS1 sequences, provided a specific and sensitive means of identifying A. invadans using DNA extracted from axenic hyphal cultures.

Phadee et al. (2004) used a different PCR assay to screen a large quantity of $A$. invadans strains isolated from various types of hosts and other oomycetes belonging to the Saprolegniaceae. They used the assay to detect $A$. invadans in experimentally challenged goldfish by applying a lower limit of detection for the assay of $500 \mathrm{fg}$ of DNA. We used their designed primer set (1APM 1F, 1APM 6R) for our study and our findings agree with their results which indicated this primer set was able to detect fish pathogenic Aphanomyces but unable to detect non-fish pathogenic Aphanomyces and saprophytic strains like A. cochlioides, A. euteiches and A. iridis (Kurata et al., 2002; Lilley et al., 2003), and is capable to diagnose $A$. invadans from both cultural fungus and fish muscle and distinguish fish pathogenic Aphanomyces from other similar fungi.

Oidtmann et al. (2006) also presented PCR based method for detection Aphanomyces.astaci causative agent of crayfish plague using primer set (5' AAG AAG GCT AAA TTG CGG TA 3') and (5' CTA TCC GAC TCC GCA TTC TG 3') which have been designed earlier (Oidtmann et al., 2004) and Primers ITS1 and ITS4 (ITS 1: 5'-TCC GTA GGT GAA CCT GCG G-3'; ITS 4: 5'-TCC TCC GCT TAT TGA TAT GC-3'). They results showed an amplicon of the expected length of 569 bp obtained with all A.astaci strains but not A.invadans and A. frigidophilus that confirmed the specificity of this primer set against $A$. invadans and A. frigidophilus.

In another study, Vandersea and their colleague (2006) developed the PCR assays that can rapidly detect $A$. invadans from naturally infected fish tissues. PCR amplification was done by using the $A$. invadans primers Ainvad-2F (5TCATTGTGAGTGAAACGGTG-3) and Ainvad-ITSR1 (5-GGCTAAGGTTTCAGTATGTAG-3). Infected fish tissues were found to be PCR-positive, and an amplicon of the expected length of $234 \mathrm{bp}$ obtained with all samples. In their study $A$. invadans zoospores were also assayed by FISH technique for hybridizing additional life cycle stages of $A$. invadans and they concluded that PCR alone could be used as a reliable diagnostic test for the presence of $A$. invadans infection. These findings are strongly support the results of present study which showed that PCR could detect EUS infection from very early stage of disease. Other studies also concluded that PCR is reliable and fast technique for detection EUS (OIE, 2013) and used this technique for different type of samples.

The PCR assays developed by Vandersea et al. (2006) study also made it possible to screen a various numbers of environmental samples and identification of the infection sources and the conditions that promote growth and 
transmission of this pathogen which will help resource managers better predict when lesion events are likely to occur and perhaps develop effective mitigation strategies.

Oidtmann et al. (2008) developed PCR assay for detection A.invadans and compared it with Phadee et al. (2004) and Vandersea et al., 2006 assays. The primers chosen for evaluation in the PCR assay were BO73 (5'-CTT GTG CTG AGC TCA CAC TC-3'; forward primer) and BO639 (5'-ACA CCA GAT TAC ACT ATC TC-3'; reverse primer) for the first round PCR. For the second round PCR primers were BO487 (5'-TGT GTT GAT ATT ACA CGA CT-3'; forward primer) and BO639 (reverse primer). They also used primer sets ITS11/ITS23 (Ballesteros et al., 2006), (1APM 1F, 1APM 6R) (Phadee et al. 2004) and Ainvad-2F/Ainvad- ITSR1 (Vandersea et al., 2006) and with all of them an amplicon of the expected size was obtained. They also notified the importance of testing whether PCR primers are fully homologous with $A$. invadans isolates from different geographical origins and species.

Oidtmann et al. (2008) also tested three-spot gourami, European catfish, rainbow trout and European eels muscles by PCR and their findings were strongly agreed with our findings where gourami was PCR-positive up to 14 dpi, catfish $19 \mathrm{dpi}$, rainbow trout $28 \mathrm{dpi}$ and uninfected eel for 6 days. Our results also showed same findings for gouramies, catfish, perch (EUS-susceptible fish) and uninfected Tilapia. The lack of detection of $A$. invadans within gouramis 6 days in European eel and Tilapia suggested that these species managed to control the infection within this time. By contrast, detection of $A$. invadans was still observed in susceptible fish after even at the time of mortality, suggesting that the affected fish were unable to eliminate the pathogen within that time.

In present study, the minimal concentration of the detection of PCR product using the primer set (1APM 1F, 1APM 6R) was 30 and $50 \mathrm{mg}$ for cultural fungus and fish muscle, respectively which were adapted with the minimal amount which used by Padaee et al. 2004. It was thought that this primer had high specificity for detecting $A$. invadans. But the detection threshold of the single round and semi-nested PCR assay in Oidtmann et al. (2008) assay was $25 \mathrm{fg}$, whereas the assays described by Vandersea et al. (2006) (2.5 pg), Phadee et al. (2004) (2 ng) and Oidtmann et al. (2004) (1 pg for detection A.astaci) appeared less sensitive. Differences in the sensitivity between the various PCR protocols can partially be explained by the different number of amplification cycles, however, the relatively low detection limit for the PCR protocol described by Phadee et al. (2004) is likely to be mainly due to a mismatch of primer and template. For this study we adapted the PCR protocol described by Phadee et al. (2004) by increasing the number of PCR cycles from 25 to 30, since we had been unable to generate a PCR product at 25 cycles with DNA from $A$. invadans isolate NJM9701. A PCR protocol must meet the required test sensitivity which depends on its engaged application. If fresh tissue material is available and intensive growth of $A$. invadans can be expected, limited analytical test sensitivity may be sufficient for the detection of $A$. invadans, however, for testing degenerated samples or samples from the aquatic animals or environment a more sensitive assay is needed. While the above PCR studies have provided valuable information, but more investigation is needed to improve protocols and develop highly sensitive PCR assays for fast and reliable detection of A.invadans in future.

\section{NOVELTY OF RESEARCH}

It is the first detection of EUS in artificially infected tropical fish by PCR technique that showed it is possible to detect infection in a very early stage of disease. We have developed DNA extraction protocol by replacing dangerous chemicals and time-consuming steps with simple, safe and fast method that is capable to extract DNA from small amount of samples.

\section{REFERENCES}

Afzali, S.F., Hassan, M.D., Mutalib A.R, A.M., Sharifpour, I. and Sabri, J. (2013). Isolation and Identification of Aphanomyces Species from Natural Water Bodies and Fish Farms in Selangor, Malaysia. Malaysian Applied Biology Journal. 42(2): 1-11.

Baldock, F.C., V. Blazer, R. Callinan, K. Hatai, I. Karunasagar, C.V. Mohan and M.G. Bondad-Reantaso. 2005.Outcomes of a short expert consultation on epizootic ulcerative syndrome EUS): Re-examination of causal factors, case definition and nomenclature. In P. Walker, R. Lester and M.G. Bondad-Reantaso (eds). Diseases in Asian Aquaculture V, pp. 555-585. Fish Health Section, Asian Fisheries Society, Manila.

Ballesteros, I., Martín, M.P., and Diéguez-Uribeondo, J. (2006). First isolation of Aphanomyces frigidophilus (Saprolegniales) in Europe. Mycotaxon. 95: 335-340.

Blazer, V.S., Lilley, J.H., Schill, W.B., Kiryu, Y., Densmore, C.L., Panyawachira, V., and Chinabut, S. (2002). Aphanomyces invadans in Atlantic Menhaden along the East Coast of the United States. Journal of Aquatic Animal Health. 14 (1): 1-10.

Hutson, K. S. (2013). Infectious Diseases of Asian Seabass and Health Management. Biology and Culture of Asian Seabass Lates Calcarifer, 102.

Jerry, D. R. (Ed.). (2013). Biology and Culture of Asian Seabass Lates Calcarifer. CRC Press.

Kurata, O., Sanpei, K., Hikiji, K., and Hatai, K. (2002). A Galactose-Binding Protein Revealed as a Hemagglutinin in Aphanomyces piscicida. Fish Pathology. 37(1): 1-6.

Lilley, J., Hart, D., Panyawachira, V., Kanchanakhan, S., Chinabut, S., Soderhall, K., and Cerenius, L. (2003). Molecular characterization of the fish pathogenic fungus "Aphanomyces invadans". Journal of Fish Diseases. 26(5): 263-275.

Oidtmann, B., Schaefers, N., Cerenius, L., Soderhall, K., and Hoffmann, R. W. (2004). Detection of genomic DNA of the crayfish plague fungus Aphanomyces astaci (Oomycete) in clinical samples by PCR. Veterinary microbiology. 100(3): $269-282$. 
Oidtmann, B., Steinbauer, P., Geiger, S., and Hoffmann, R. W. (2008). Experimental infection and detection of Aphanomyces invadans in European catfish, rainbow trout and European eel. Diseases of Aquatic Organisms. 82(3): $195-207$.

OIE. (2013). Infection with Aphanomyces invadans (Epizootic Ulcerative Syndrome). OIE Aquatic Animal Health Standards Commission. www.oie.int/international-standard-setting/aquatic-manual/access-online.

Phadee, P., Kurata, O., Hatai, K., Hirono, I., and Aoki, T. (2004). Detection and identification of fish-pathogenic Aphanomyces piscicida using polymerase chain reaction (PCR) with species-specific primers. Journal of Aquatic Animal Health. 16(4): $220-230$.

Shariff, M., Soon, S., Lee, K.L., and Tan, L.T. (2000). Practical problems with PCR detection in Asia: the importance of standardization. DNA-Based Molecular Diagnostic Techniques: Research Needs for Standardisation and Validation of the Detection of Aquatic Animal Pathogens and Diseases. 45-51.

Tang, Y.W., Procop, G.W., and Persing, D.H. (1997). Molecular diagnostics of infectious diseases. Clinical chemistry. 43(11): $2021-2038$.

Vandersea, M.W., Litaker, R.W., Yonnish, B., Sosa, E., Landsberg, J.H., Pullinger, C., Moon-Butzin, P. (2006). Molecular assays for detecting Aphanomyces invadans in ulcerative mycotic fish lesions. Applied and environmental microbiology. $72(2)$ : 1551. 